\title{
GIT2 wt Allele
}

National Cancer Institute

\section{Source}

National Cancer Institute. GIT2 wt Allele. NCI Thesaurus. Code C52634.

Human GIT2 wild-type allele is located in the vicinity of 12 q24.1 and is approximately 66 $\mathrm{kb}$ in length. This allele, which encodes ARF GT Pase-activating protein GIT2, plays a role in the mediation of both cellular adhesion and migration. 